\title{
Castor polyurethane used as osteosynthesis plates: microstructural and thermal analysis
}

\author{
Francisco Norberto de Moura Neto ${ }^{1}$, Ana Cristina Vasconcelos Fialho ${ }^{1 *}$ (D), Walter Leal de Moura ${ }^{1}$, \\ Adriana Gadelha Ferreira Rosa', José Milton Elias de Matos², Fernando da Silva Reis², \\ Milton Thélio de Albuquerque Mendes² and Elton Santos Dias Sales ${ }^{3}$
}

\author{
${ }^{1}$ Departamento de Patologia e Clínica Odontológica, Universidade Federal do Piauí - UFPI, \\ Teresina, PI, Brasil \\ 2Fismat, Departamento de Química, Universidade Federal do Piauí - UFPI, Teresina, PI, Brasil \\ ${ }^{3}$ Laboratório de Engenharia de Materiais, Programa de Pós-graduação, Departamento de Engenharia de \\ Materiais, Instituto Federal do Piauí - IFPI, Teresina, PI, Brasil \\ *anacrisvf@gmail.com
}

\begin{abstract}
Bone fractures to be corrected need stabilization of their extremities, which is achieved with the use of plates and screws. This research aimed to produce castor bean polyurethane (Ricinus communis), to make resorbable plate, structural and thermal analysis. The production was made by the glycerolysis of the triglycerides present in the oil, after addition of polyol/glycerol and hexamethylene diisocyanate (HDI) to form urethane structures, with and without addition of hydroxyapatite. The characterization was by FTIR spectroscopy, scanning electron microscopy (SEM), $\mathrm{X}$-ray diffraction, differential scanning calorimetry and thermogravimetry. Plates with dimensions of $40 \mathrm{~mm} \mathrm{X} 10 \mathrm{~mm}$ X $2 \mathrm{~mm}$ were obtained. The SEM showed flat and homogeneous surface. DRX analysis showed the semi-crystallinity of the biomaterial. Glass transition and thermal stability up to $50{ }^{\circ} \mathrm{C}$ were observed, followed by thermal decomposition up to $450^{\circ} \mathrm{C}$. The produced polyurethane showed it is possible to be applied in the manufacture of plate.
\end{abstract}

Keywords: maxillofacial surgery, fracture fixation, bone fractures, biocompatible materials, castor oil.

How to cite: Moura Neto, F. N., Fialho, A. C. V., Moura, W. L., Rosa, A. G. F., Matos, J. M. E., Reis, F. S., Mendes, M. T. A., \& Sales, E. S. D. (2019). Castor polyurethane used as osteosynthesis plates: microstructural and thermal analysis. Polímeros: Ciência e Tecnologia, 29(2), e2019029. https://doi.org/10.1590/0104-1428.02418

\section{Introduction}

The technique of functionally stable fixation of bone fractures consists of stabilizing the segments with plates and screws in direct contact with the structure, allowing new ossification. Titanium is the most used material because it is bioinert and possesses high mechanical resistance, allowing the bone to exert its function during the repair process, even with the occurrence of micromovements between the fragments ${ }^{[1]}$.

Some problems are associated with the use of titanium plates. Interference in imaging tests, bone atrophy, pain, cold hypersensitivity and impairment of bone growth in children are the most cited. Due to being more rigid, the metallic material absorbs most of the incident forces, which may lead to reduction of bone density (stress-shielding phenomenon). There is still no consensus on the need for additional surgical intervention for the removal of the metallic material after the consolidation of the fracture ${ }^{[2]}$.

Polymers and composites, like hydroxyapatite/polymer properties, represent an alternative for the treatment of facial fractures because they have elastic modulus close to the bone and they are resorbable. The metabolism of these devices takes place in a concomitant period bone union, without leaving any by-products in the body. Resorbable plates and screws still present problems such as low mechanical resistance and inadequate design compared to titanium; besides the induction of inflammatory response during the hydrolysis of its molecules ${ }^{[3]}$.

Copolymers of polylactic acid (PLA) and polyglycolic acid (PGA), unstable polyesters in wet conditions are the most widely used biodegradable devices ${ }^{[4,5]}$. The polymer derived from castor oil (Ricinus communis) was released for medical and dental use by the Ministry of Health in 1999 and also the Food and Drug Administration (FDA) in 2003. Because it is both biocompatible and osteoconductive, it allows the growth of connective tissue and bone within its pores and assists in the stability of the surgical apparatus ${ }^{[1]}$. To improve the osteoconductivity of the polymer, bioactive ceramics, such as hydroxyapatite, have been combined to produce polymer composite due to their similar chemical structure with human bone tissue. Hydroxyapatite is the main inorganic component of the tissues of vertebrates and artificially synthesized as bioactive (osteoconductivite) and it also has the ability to encourage bone growth ${ }^{[1-5]}$. 
The biocompatibility of resorbable polymers for fracture fixation is well established, but most of them hold high prices. The applicability of a biomaterial in the medical and dental area depends on its mechanical characteristics, biodegradation and microstructure features ${ }^{[6]}$. The study of castor oil polymer and hydroxyapatite/castor oil composite, a bone analog model, is justified by the possibility of local production of a resorbable biomaterial as an alternative in the treatment of facial fractures, with lower cost for use in the public service and also in pediatric patients. The purpose of this work was to develop polyurethane obtained by the chemical processing of castor oil and describe its microstructure and thermal characteristics for the production of resorbable plate for fixation of bone fractures.

\section{Materials and Methods}

\subsection{Synthesis of the biocomposite from castor oil}

The experiment was carried out at the Materials Physics Laboratory of the Federal University of Piauí (FISMAT-UFPI). All samples of castor oil, extracted from the seeds of the Ricinus communis plant, had a production and quality certification; and they were initially analyzed for acidity, iodine, peroxide index, viscosity, and density; to confirm the physicochemical specifications provided by the manufacturer.

\subsection{Oil catalysis and production of monoacylglycerol}

The initial stage for the production of biopolymer was the glycerolysis reaction of the triglycerides present in the castor oil structure, after addition of polyol (glycerol). To achieve this, an amount of the oil $(40 \mathrm{~g})$ was weighed and mixed to glycerol $(7.9 \mathrm{~g})$ to give a suitable molar ratio. After stirring, the catalyst Lithium Hydroxide ( $\mathrm{LiOH}, 0.02 \mathrm{~g}$ ) was added. The mixture was then placed in a round bottom flask for magnetic stirring and reaction mixture in a suitable atmosphere, with controlled time (5h) and temperature $\left(140^{\circ} \mathrm{C}\right)$; until obtaining monoacylglycerol (MAG), a resin with a gelatinous appearance.

\subsection{Synthesis of hydroxyapatite (HA)}

Calcium hydroxide $\left[\mathrm{Ca}(\mathrm{OH})_{2}, 1.5 \mathrm{~g}\right]$ and ammonium phosphate $\left[\left(\mathrm{NH}_{4}\right)_{3} \mathrm{PO}_{4}, 1,6 \mathrm{~g}\right]$ were initially added, which in aqueous solution they formed a characteristic white suspension. The solution was stirred for a predetermined time $(2: 30 \mathrm{~h})$, then it was oven dried at $120^{\circ} \mathrm{C}$ for $12 \mathrm{~h}$, then centrifuged and washed. Finally, it was placed to dry at $300{ }^{\circ} \mathrm{C}$ for $6 \mathrm{~h}$.

\subsection{Preparation of polyurethane}

The synthesized monoacylglycerol (which has the structure of a polyol) was mixed with Hexamethylene Diisocyanate (HDI), with a suitable stoichiometric ratio. The mixture was placed in a volumetric flask and heated to $95^{\circ} \mathrm{C}$ with constant stirring in a controlled environment. After that, hydroxyapatite was added to obtain a concentration of $3 \%$ by mass, relative to the mass of the monoacylglycerol. After homogenization, the mixture was collected and stored in a suitable container. During the final phase of the polyurethane reaction, when the material reaches the "gel point", the mixture was placed in a rectangular shaped container, closed by a device (cover) and fastened with screws. The mold was pressed for completion of the polymerization reaction.

\subsection{Spectroscopic analysis in the infrared region (FTIR)}

The FTIR spectra of the synthesized monoacylglycerol and polyurethane samples were obtained in a Thermo Fisher SCIENTIFIC Nicolet iS5 spectrophotometer with purge pump and wavelength between $400 \mathrm{~cm}^{-1}$ and $4000 \mathrm{~cm}^{-1}$, 128 accumulated scans, $4 \mathrm{~cm}^{-1}$ resolution, in ATR, in Transmittance module. The method was used to verify the conclusion of the curing reaction of polyurethane and the presence of free isocyanate functional groups (NCO) after the reaction ${ }^{[7]}$.

\subsection{Scanning Electron Microscopy (SEM)}

To perform Electron Microscopy, it was used FEI Quanta 250 FEG-equipment. Since it was a polymeric material, surface preparation was necessary. All samples were fractured in liquid nitrogen and coated with a gold layer to obtain better conductivity. A piece was deposited in the aluminum substrates. For this purpose, the samples were coated with gold in order to avoid the accumulation of charges that repel the incident electron beam. The micrographs served to observe the morphology and particle size of polyurethane $\mathrm{e}^{[7,8]}$.

\subsection{X-ray Diffraction Analysis (XRD)}

Polyurethane samples were analyzed for their microstructure by means of X-ray diffraction (XRD), Labx - XDR 600 equipment from Shimadzu with $\mathrm{Cu}$-Ka radiation $(\lambda=1.5406 \AA), 2 \theta$ in the range between $50^{\circ}$ to $750^{\circ}$, scan rate of $2^{\circ} / \mathrm{min}$ and total exposure time of 40 minutes. The objective was to identify the crystalline peaks, the crystalline and amorphous phases and also calculate the parameters of the crystalline network of the biomaterial ${ }^{[9]}$.

\subsection{Differential Scanning Calorimetry (DSC) and Thermogravimetric Analysis (TGA)}

The DSC curve was obtained from TA Instruments; model Q2000, with temperature range between $-150^{\circ} \mathrm{C}$ and $600^{\circ} \mathrm{C}$. The TG curve was obtained in Q50, TA Instruments, with a temperature range between $25^{\circ} \mathrm{C}$ and $1200{ }^{\circ} \mathrm{C}$; both under nitrogen atmosphere, heating rate of $10 \% \mathrm{~min}$ and sample of $10 \mathrm{mg}$. The DSC technique was used to determine the temperature transitions of the physical state of the polyurethane. Thermogravimetry was used to study the stability range and thermal decomposition mechanisms of the material ${ }^{[7-9]}$.

\subsection{Descriptive Statistics}

Five samples of the monoacylglycerol and polyurethane obtained were analyzed by means of FTIR spectroscopy, and five polyurethane samples were evaluated by MEV, XRD, DSC, and TG. It was conducted a descriptive analysis of the following parameters: formation of the monoacylglycerol and polyurethane structure; characteristics of crystallinity and conformation of the molecules; in addition to the glass transition temperature, melting temperature, and the degradation onset temperature. 


\section{Results and Discussion}

\subsection{Castor oil catalysis and physicochemical characterization}

Castor oil presents in its composition $89.5 \%$ to $90 \%$ triglyceride ricinoleic acid (12-hydroxy-cis-9-octadecenoic acid), whose molecular formula is $\mathrm{C}_{17} \mathrm{H}_{32} \mathrm{OHCOOH}$. In the ester bonds of the triglyceride (1st carbon) reactions of hydrolysis, esterification, alcoholysis and, halogenation can occur (Figure 1) ${ }^{[9-12]}$.

In the present study, the glycerolysis pathway of the triglycerides present in the oil was used (Figure 2). The alkoxide is an active radical formed by the reaction of glycerol with lithium hydroxide (catalyst) (A). The $\mathrm{C}=\mathrm{O}$ (carbonyl) bond of the triglyceride undergoes nucleophilic attack by alkoxide, forming a tetrahedral intermediate. After rearrangement of this intermediate, a monoalcohol ester and the anion are formed, which, upon deprotonation of the conjugate acid from the base formed in the reaction, it regenerates lithium hydroxide and produces a diglyceride (B). Similar reactions occur with diglycerides, with formation of monoacylglycerol (MAG) (C) ${ }^{[13]}$.

\subsection{Formation and preparation of polyurethane plates}

A urethane structure is the result of the chemical reaction between an isocyanate group and a hydroxyl radical.The synthesis of a high molar mass polyurethane (Figure 3) occurs when isocyanate groups react with a polyfunctional alcohol (hydroxylated polymer or polyol). In this research, the Hexamethylene Diisocyanate (HDI) was used, molecular formula $\mathrm{C}_{8} \mathrm{H}_{12} \mathrm{O}_{2} \mathrm{~N}_{2}$ and molecular structure $\mathrm{OCN}-\left(\mathrm{CH}_{2}\right)_{6}-\mathrm{NCO}$. Although less reactive, HDI

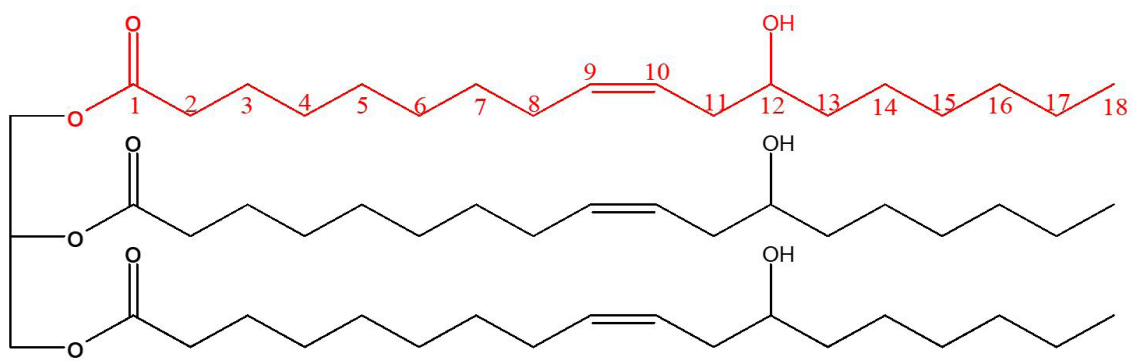

Figure 1. Scheme of chemical structure of ricinoleic acid, the primary component of castor oil.

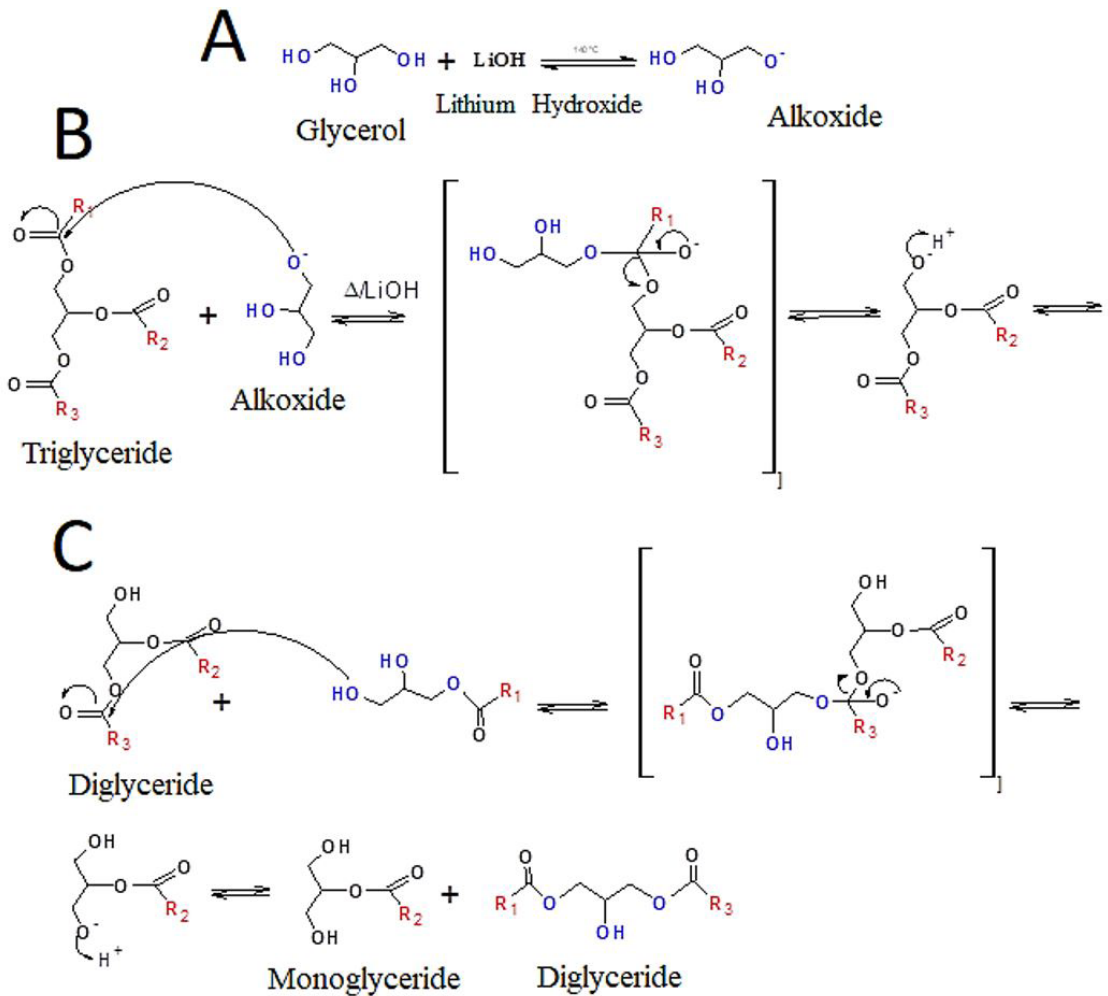

Figure 2. Scheme of catalysis of the triglyceride present in castor oil. (A): obtainment of the alkoxide as the catalyst; (B): breakdown of the triglyceride molecule; $(\mathrm{C})$ : molecules of monoglyceride and diglyceride were formed. 

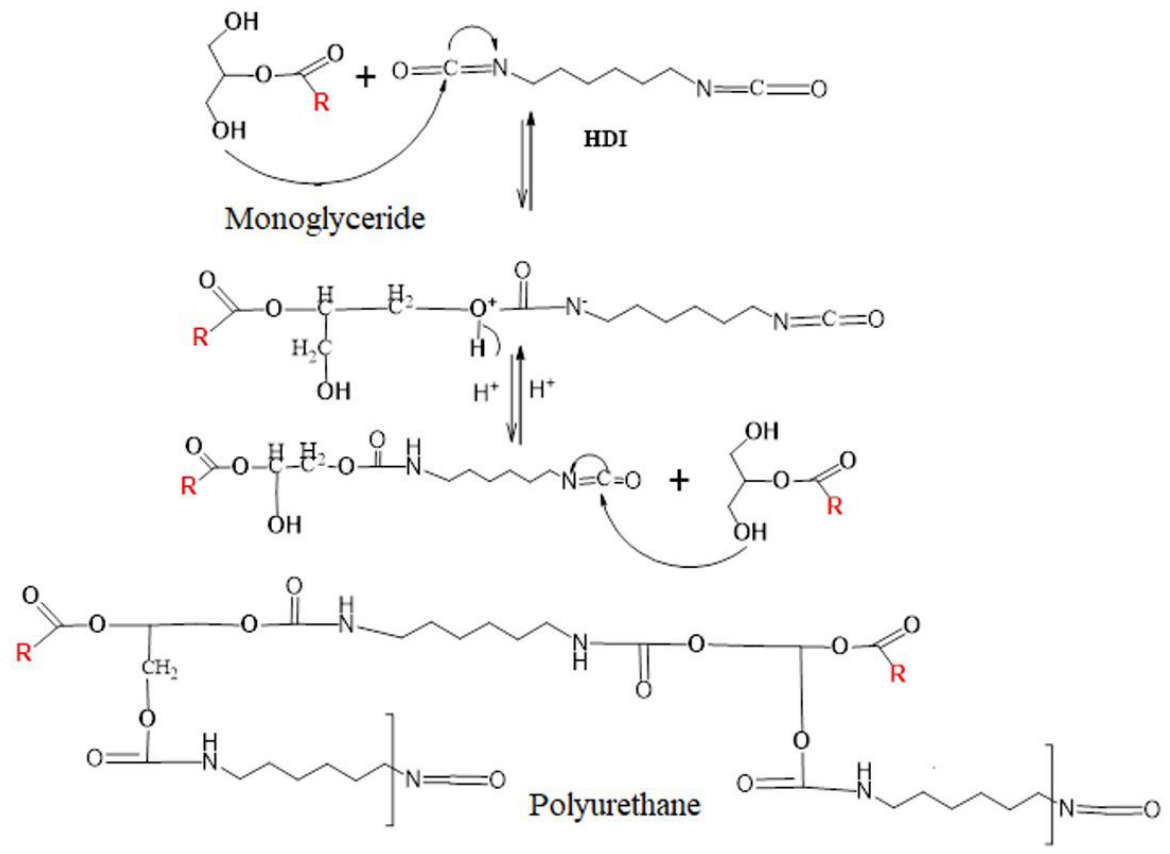

Figure 3. Scheme of mechanism proposed for the reaction between monoglyceride and Hexamethylene Diisocyanate (HDI), with the formation of castor oil polyurethane.

is less volatile and less toxic because the composition does not have benzene ${ }^{[13,14]}$.

The reaction begins with the attack of the nucleophilic center of the MAG (monoacylglycerol) on the electrophilic carbon of the carbonyl group $(\mathrm{C}=\mathrm{O})$ of the isocyanate; the proton is simultaneously transferred to the nitrogen atom. A urethane structure is formed when the hydrogen atom of the hydroxyl group present in the MAG binds to the nitrogen atom of the isocyanate group. The mechanism repeats until the formation of the polyurethane structure ${ }^{[13]}$.

During the final reaction of polyurethanes, curing agents, blowing agents, catalysts and fillers may be incorporated. Hydroxyapatite is a biocompatible and osteoconductive material, serving as a structure for the migration of osteoprogenitor cells ${ }^{[8-10]}$. The last step to obtain the composite was conducted through the addition of hydroxyapatite. The mixture was stored in a suitable container in order to wait for curing time of the material. Samples of the pure polyurethane and proportion of hydroxyapatite at 3\% by mass were obtained (Figure 4).

\subsection{Analysis by infrared spectroscopy (FTIR)}

Figure 5 shows the FTIR spectrum for the monoacylglycerol obtained from castor oil. The main absorption bands and their functional groups are highlighted.

The absorption region between 3300 and $3250 \mathrm{~cm}^{-1}$ is related to drawability of the $\mathrm{OH}$ group; the absorption bands between 3000 and $2750 \mathrm{~cm}^{-1}$ are characteristics of the stretching mode of the $\mathrm{CH}, \mathrm{CH}_{2}$ and $\mathrm{CH}_{3}$ groups; the $1750 \mathrm{~cm}^{-1}$ region is characteristic of carbonyl stretch $(\mathrm{C}=\mathrm{O})$; the absorption bands between 1500 and $1250 \mathrm{~cm}^{-1}$ is characteristic of the deformation of the $\mathrm{CH}_{2}$ and $\mathrm{CH}_{3}$ groups;

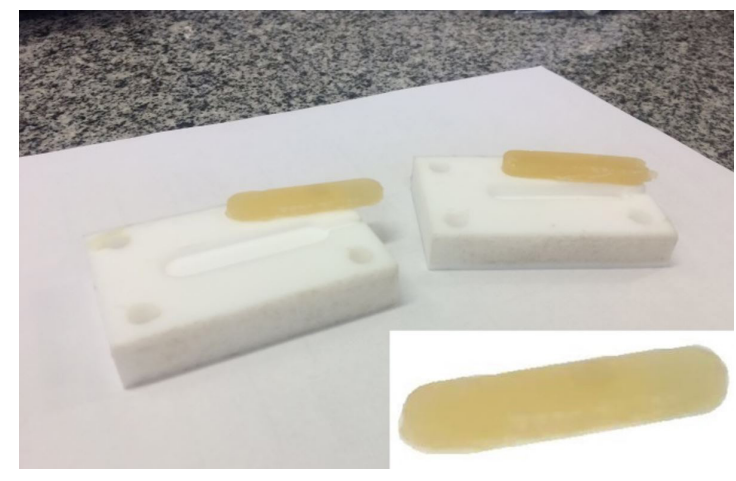

Figure 4. Photography of polyurethane castor oil (COP) resorbable plates, with dimensions of $40 \mathrm{~mm} \times 10 \mathrm{~mm} \times 2 \mathrm{~mm}$.

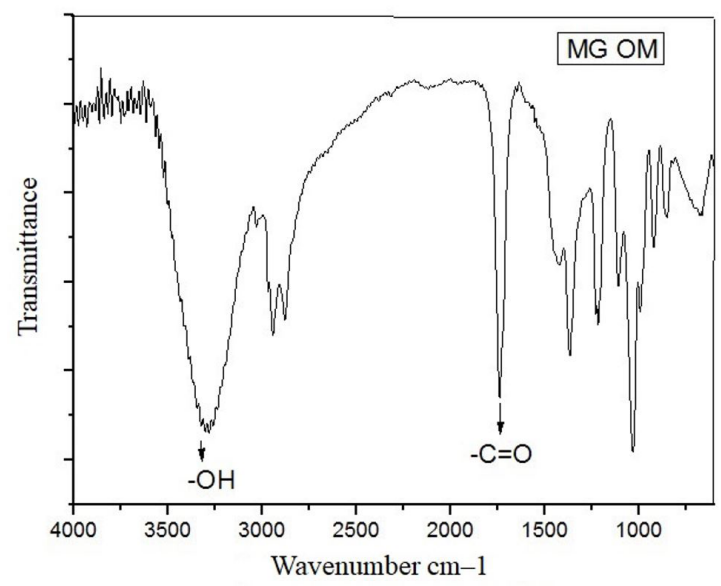

Figure 5. FTIR spectrum of monoglyceride molecules. 
the absorption bands between 1250 and $1150 \mathrm{~cm}^{-1}$ refer to the $\mathrm{C}-\mathrm{O}$ and $\mathrm{C}-\mathrm{C}$ bonds; the band region at $1100 \mathrm{~cm}^{-1}$ is also characteristic of the stretching of $\mathrm{C}-\mathrm{O}$ bonds and ester (-C-O-C-) group; finally, "wag" vibrations and asymmetric angular deformation of the $\mathrm{CH}$ and $\mathrm{CH}_{2}$ groups are observed in the bands at $750 \mathrm{~cm}^{-1}[15-18]$.

The FTIR analysis performed on the polyurethane samples obtained by the chemical processing of castor oil with addition of $3 \%$ hydroxyapatite (HA) is shown in Figure 6. It is possible to observe the regions that prove the formation of the polymer.

The absorption band at $3315 \mathrm{~cm}^{-1}$ is characteristic of the $\mathrm{N}-\mathrm{H}$ urethane bond. The regions of $2939 \mathrm{~cm}^{-1}$ and $2852 \mathrm{~cm}^{-1}$ are asymmetric and symmetrical stretching characteristics of $\mathrm{CH}_{3}$, respectively ${ }^{[15,16]}$. According to Pradhan and Nayak ${ }^{[9]}$, these regions are characteristics of the stretching of the $\mathrm{CH}_{2}$ and $\mathrm{CH}_{3}$ groups. The carbonyl stretching band $(\mathrm{C}=\mathrm{O})$ was shifted to $1730 \mathrm{~cm}^{-1}$. The $1530 \mathrm{~cm}^{-1}$ region is characteristic of the amide $\mathrm{NH}$ deformation in the groups. The formation of polyurethane is also indicated by the absence of band in the region of absorption between 2350 and $2100 \mathrm{~cm}^{-1}$, relative to the $\mathrm{N}=\mathrm{C}=\mathrm{O}$ group, indicating no free isocyanate functional groups ${ }^{[17-19]}$.

\subsection{Scanning Electron Microscopy (SEM)}

Figure 7 shows the microstructural analysis by Electron Microscopy of the polyurethane derived from castor oil without addition of hydroxyapatite. Flat and homogeneous surface, with evenly distributed protrusions and depressions; besides clearer granular structures suggestive of artifacts by residual material was observed.

The surface characteristics corroborate with the results obtained by Monteiro et al. ${ }^{[20]}$, who analyzed the ultrastructure of polyurethane and membranes for bone regeneration, and it was observed a flat and homogeneous surface, protrusions and depressions with an irregular outline, besides granular structures of various sizes. Nacer et al. ${ }^{[6]}$ and Marano and Tincani ${ }^{[21]}$ state that the porous surface of the castor oil polymer promotes bone migration and deposition, behaving as a passive structure that allows osteoconduction.

The synthesized hydroxyapatite powder showed homogeneous spherical granular surface appearance, with granules sometimes agglomerated, sometimes spaced apart. Costa et al. ${ }^{[22]}$ also analyzed the microstructure of HA in SEM and it was observed granular surface and also the presence of pores, which are important characteristics for biomedical applications, since they favor the adhesion between the neoformed bone tissue and the synthetic apatite.

Figure 8 shows the microphotograph of polyurethane with addition of $3 \%$ HA. According to Pradhan and Nayak ${ }^{[9]}$, the gray regions indicate the polymer matrix and the bright spots indicate the distribution of hydroxyapatite particles.

Polymers with modulus of elasticity similar to that of bone structure allow a better distribution of forces between bone and implant. Bioactive ceramics such as hydroxyapatite have limited individual use because of the low fracture toughness. The HA/polymer composite structure resembles natural bone tissue, increasing the surface area, harboring cells and contributing to the production of organic matrix within the implant ${ }^{[23,24]}$.

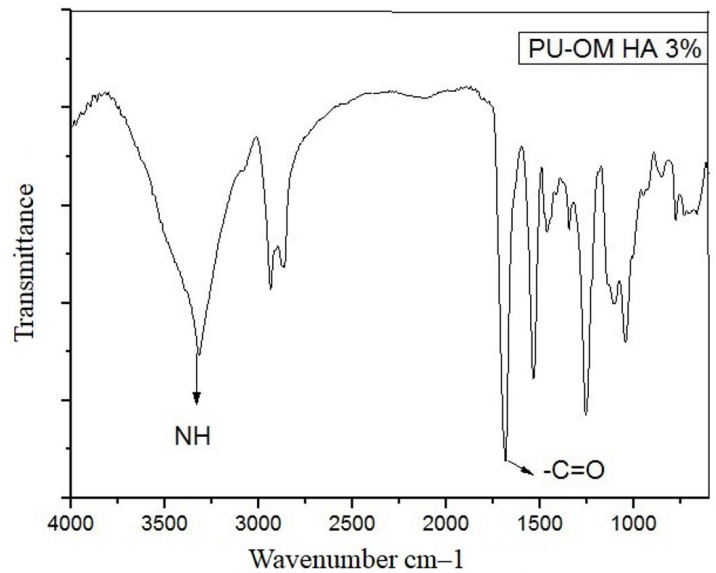

Figure 6. FTIR spectrum of castor oil polyurethane with addition of $3 \% \mathrm{HA}$.

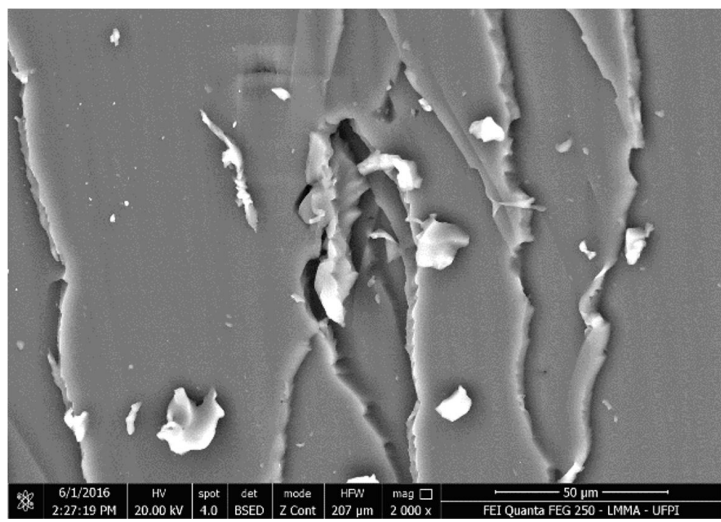

Figure 7. SEM image (2000x). Polymer with flat and regular surface; artifacts.

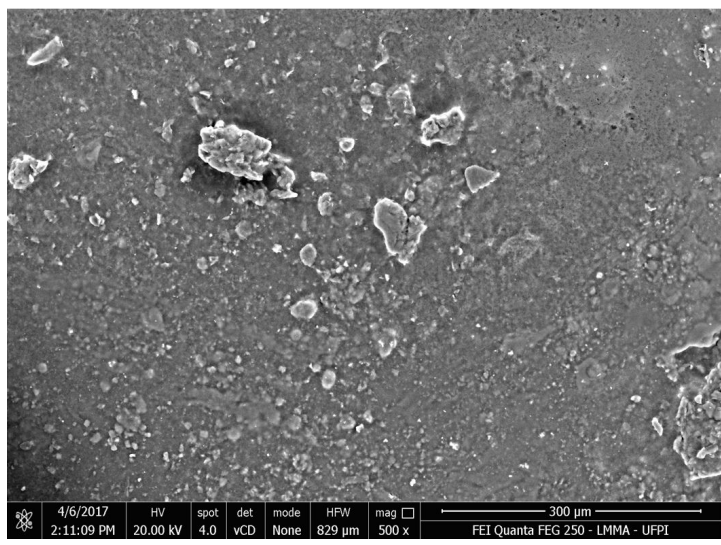

Figure 8. Microphotograph (500x) of the biopolymer with 3\% HA, showing bright scattered appearance related to the filler.

However, Alves et al. ${ }^{[25]}$ mechanically evaluated the $70 \%$ polyhydroxybutyrate and $30 \%$ hydroxyapatite composite in the form of plate for bone fixation, and it was observed that the addition of HA in the polymer matrix caused reduction in the mechanical strength of the composites, because the particles acted as distributed defects in the organic matrix. 


\subsection{X-ray diffraction $(X R D)$}

Figure 9 shows the Bragg-Brentano profile of the samples of the polymer with addition of $3 \%$ HA. Diffraction peaks around $195.2^{\circ}$ are characteristic of semi-crystalline materials. The orderly packaging of the molecular chains is one of the main aspects of the crystallinity of a polymer. Lack of chain alignment during solidification results in an amorphous region ${ }^{[9,26]}$.

The degree of crystallinity also depends on the number of branches present and also the rate of cooling. The crystallinity of a biomaterial influences its in vivo performance by affecting reabsorption and its mechanical properties. It is known that amorphous regions are reabsorbed more rapidly and materials with more organized structure generally have a slower rate of resorption ${ }^{[27,28]}$.

Lin et al. ${ }^{[17]}$ introduced acetylated cellulose nanocrystals in the castor oil polyurethane formulation in order to strengthen the material. After analysis by X-ray diffraction, it was observed that for the concentrations of 5 and $10 \%$ by weight of cellulose there was no change in the reflection planes in relation to the pure polymer. Only with increasing charge concentration to 15 and $25 \%$, characteristic crystallinity diffraction peaks were observed.

The molecules of the polymers are generally semicrystalline, dispersed within the remaining amorphous material. The volumetric biodegradation of polyurethanes occurs by diffusion of water through amorphous regions, hydrolysis of ester linkages of the main chain and decrease in volume and molar mass when the polymer begins to fragment. Degradation products containing carboxyl induce further degradation by autocatalysis. Then, the hydrolysis of the crystalline regions, enzymatic attack and the metabolism of the fragments occur ${ }^{[27,29-31]}$. The observed microstructure and crystalline aspects suggest that the biodegradation of polymers produced after coming into contact with body fluids under physiological conditions will occur through the volumetric erosion mechanism.

\subsection{Differential Scanning Calorimetry (DSC) and Thermogravimetry (TG)}

The Figure 10 (DSC) shows the heat energy flux associated with the transitions in the material as a function of temperature, and the Figure 11 (TG) shows the mass variation of polyurethane as a function of temperature; both obtained under the same experimental conditions. It is essential to compare the DSC and TG curves simultaneously since the first one detects events associated or not with mass loss, while TG indicates only thermal events related to material mass changes ${ }^{[7]}$. Thermal events of physical state change can be attributed from the DSC curve, provided that in the same temperature range of the TG curve no mass loss events are observed ${ }^{[8,9]}$.

The temperature range of $50{ }^{\circ} \mathrm{C}$ was attributed to the glass transition of the polymer produced, since the baseline displacement in the endothermic direction was observed in Figure 10 (DSC), without significant mass loss in TG (Figure 11). This glass transition range, without peaks characteristic of phase transformations such as melting or recrystallization indicates the predominance of the

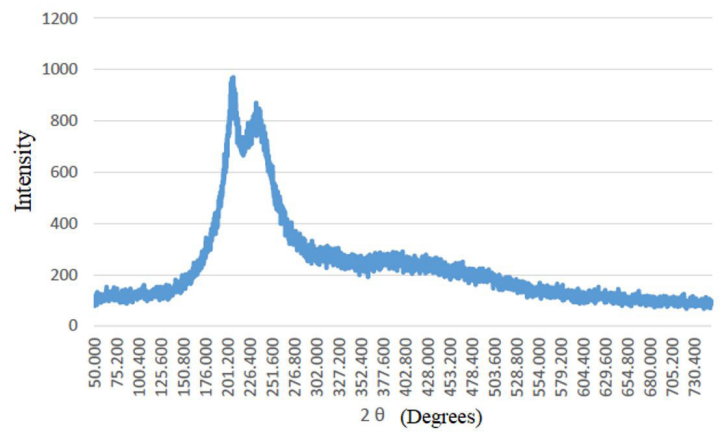

Figure 9. Diffractogram of Biopolymer with 3\% hydroxyapatite, with a crystallinity peak around $195.2^{\circ}$ which characterizes the semi-crystallinity of the material.

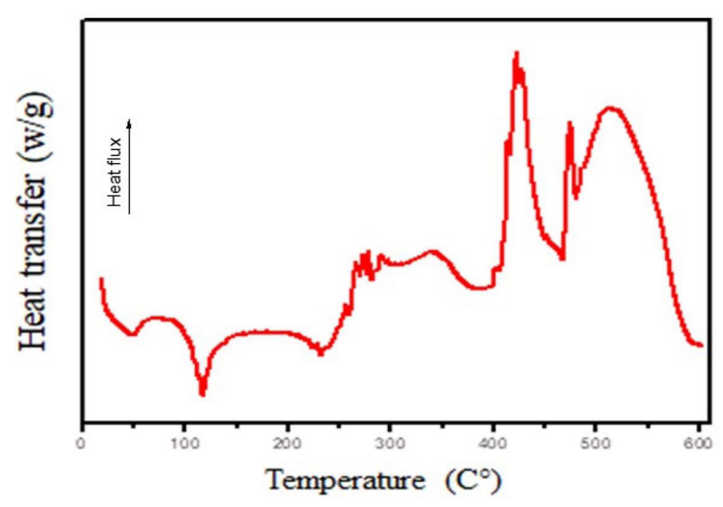

Figure 10. DSC curve of castor oil polyurethane with $3 \%$ hydroxyapatite.

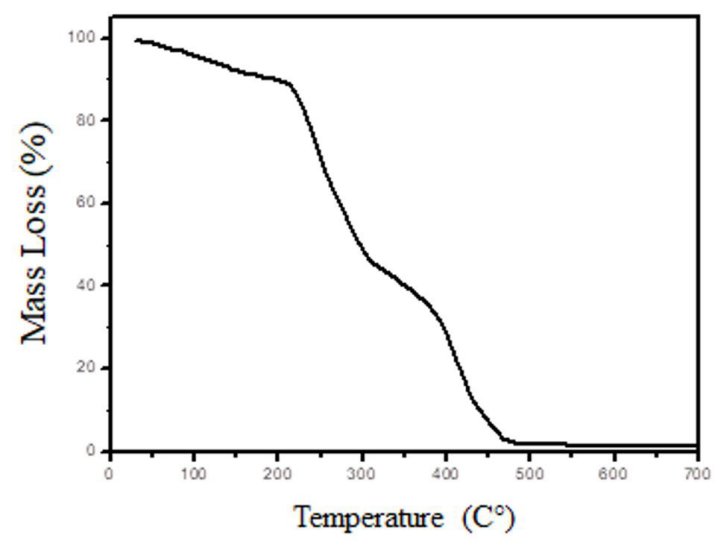

Figure 11. TG curve of castor oil polyurethane with $3 \%$ hydroxyapatite.

amorphous phase in the biomaterial ${ }^{[7,8]}$. The other energy flux peaks in DSC coincide with mass loss events in TG. It is possible to observe two endothermic peaks at approximately 120 and $230{ }^{\circ} \mathrm{C}$; and exothermic peaks between 250 and $300^{\circ} \mathrm{C}$, between 400 and $450{ }^{\circ} \mathrm{C}$ and above $450{ }^{\circ} \mathrm{C}$ (DSC); all accompanied by mass loss.

Polyurethanes generally decompose into two or three events due to structural differences ${ }^{[15,16]}$. The biomaterial showed thermal stability up to $50^{\circ} \mathrm{C}$, from which two thermal 
decomposition peaks and reduction of the initial sample mass were observed, which one peak was in the range of 200 to $250^{\circ} \mathrm{C}$ and another peak was in the $350^{\circ} \mathrm{C}$ temperature range (Figure 11). It is verified that the degradation process occurred in different stages.

Between 50 and $200{ }^{\circ} \mathrm{C}$, the loss of approximately $10 \%$ of the initial mass resulted from the physical degradation of smaller groups, evaporation of solvent molecules and volatile organic compounds from the sample ${ }^{[16-26]}$. Between 200 and $300{ }^{\circ} \mathrm{C}$, the loss of $50 \%$ of the mass occurred. This step involves the decomposition of unsaturated fatty acids; dissociation of polyurethane into isocyanates and alcohol, breaking of biuret, allophanate, ester and urethane linkages; dissociation of polyurethane into isocyanates and alcohol, break of biuret bonds, allophanate, ester and urethane linkages; and the formation of transition components such as amines and carbon dioxide ${ }^{[16-26]}$.

The remainder of the mass was lost between 300 and $450{ }^{\circ} \mathrm{C}$ and above $450{ }^{\circ} \mathrm{C}$. These stages are characterized by the remaining degradation of the polyol, decomposition of the major functional polyurethane groups and also of the flexible parts of the chain, dehydrogenation of alkyl groups present in monoacylglycerol; and thermolysis of the organic residues from previous steps, scission of carbon-carbon bonds and additional oxidation of the crosslinked network, respectively ${ }^{[10,15,26]}$

All the characterizations performed reached the necessary requirements for the production of a bioabsorbable plate. Considering that plates for fixation of bone fractures ought to allow adequate reduction of fracture, alignment of the ends of the bone fragments and bone repair with the bone callus formation and bone remodeling. The biodegradation should occur during the process of bone repair, not yet determined, and it is related to contact of the plates with body fluids, temperature and movement of the anatomical area. The characteristics of the material such as crystallinity and geometric shape are considered important for biodegradation process $^{[4,24,32]}$.

\section{Conclusions}

Polyurethane in the form of resorbable plate for fixation of bone fractures was obtained by the chemical processing of castor oil.Absorption bands characteristic of the $\mathrm{OH}$ and carbonyl groups $(\mathrm{C}=\mathrm{O})$ were evidenced by the FTIR analysis of the monoacylglycerol obtained. FTIR analysis of polyurethane with 3\% HA showed regions demonstrating the formation of the polymer.

SEM analysis showed flat and homogeneous surface of polyurethane and shiny aspects of the filler material (hydroxyapatite). Characteristics of semicrystalline polymers were observed in X-ray diffraction analysis. The suggested degradation mechanism was of the volumetric type.

After analysis in Differential Scanning Calorimetry (DSC) and Thermogravimetry (TGA), the temperature range of $50{ }^{\circ} \mathrm{C}$ was attributed to the glass transition and thermal stability of the polymer produced, from which mass reduction and two thermal decomposition peaks were observed. These results demonstrate the possibility of applying the biopolymer under physiological conditions.
Mechanical assays will be conducted in order to evaluate the influence of the addition of hydroxyapatite and the plasticizer polyethylene glycol (PEG) as a way to increase the strength and the elastic modulus of polyurethane during application in the functionally stable fixation technique.

\section{Acknowledgments}

The authors would like to thank the Piauí Research Support Foundation - FAPEPI (process EFP 00012113 of W. L, Moura), and CNPq (process 310769/2014-0 and 310769/2014-0 of J. M. E. Matos). The authors declare that they have no conflict of interest

\section{References}

1. Morita, A. T., Toma, M. S., \& de Paoli, M.-A. (2005). Módulo de reometria capilar e auto-reforçamento de baixo custo. Polímeros: Ciência e Tecnologia, 15(1), 68-72. http://dx.doi. org/10.1590/S0104-14282005000100015.

2. Kang, I. G., Jung, J. H., Kim, S. T., Choi, J. Y., \& Sykes, J. M. (2014). Comparison of Tiatium and Biodegradable Plates for Treating Midfacial Fractures. Journal of Oral and Maxillofacial Surgery, 72(4), 762.e1-762.e4. http://dx.doi.org/10.1016/j. joms.2013.12.020.

3. Milori, F. P., Quitzan, J., Souza, R. S., Cirio, S. M., Dornbusch, P. T., \& Prado, A. M. R. B. (2013). Placas ósseas confeccionadas a partir de diáfise cortical equina na osteossíntese femoral em coelho. Pesquisa Veterinária Brasileira, 33(10), 1201-1207. http://dx.doi.org/10.1590/S0100-736X2013001000005.

4. Park, Y. W. (2015). Bioabsorbable osteofixation for orthognathic surgery. Maxillofacial Plastic and Reconstructive Surgery, 37(1), 6. https://doi.org/10.1186/s40902-015-0003-7. PMid:25722967.

5. Erbetta, C. D. C., Viegas, C. C. B., Freitas, R. F. S., \& Sousa, R. G. (2011). Síntese e caracterização térmica e química do copolímero poli(D,L-lactídeo-co-glicolídeo). Polímeros: Ciência e Tecnologia, 21(5), 376-382. http://dx.doi.org/10.1590/ S0104-14282011005000063.

6. Nacer, R. S., Silva, B. A. K., Poppi, R. R., Silva, D. K. M., Cardoso, V. S., Delben, J. R. J., \& Delben, A. A. S. T. (2015). Biocompatibility and osteogenesis of the castor bean polymer doped with silica $\left(\mathrm{SiO}_{2}\right)$ or barium titanate $\left(\mathrm{BaTiO}_{3}\right)$ nanoparticles. Acta Cirurgica Brasileira, 30(4), 255-263. http://dx.doi. org/10.1590/S0102-865020150040000004. PMid:25923258.

7. Merlini, C., Soldi, V., \& Barra, G. M. O. (2011). Influence of fiber surface treatment and length on physico-chemical properties of short random banana fiber-reinforced castor oil polyurethane composites. Polymer Testing, 30(8), 833-840. http://dx.doi.org/10.1016/j.polymertesting.2011.08.008.

8. Marinho, N. P., Nascimento, E. M., Nisgoski, S., Magalhães, W. L. E., Neto, S. C., \& Azevedo, E. C. (2013). Caracterização física e térmica de compósito de poliuretano derivado de óleo de mamona associado com partículas de bambu. Polímeros Ciência e Tecnologia, 23(2), 201-205.

9. Pradhan, K. C., \& Nayak, P. L. (2012). Synthesis and characterization of polyurethane nanocomposite from castor oil- hexamethylene diisocyanate (HMDI). Advances in Applied Science Research, 3(5), 3045-3052. Retrieved in 2018, June 20, from: http://www.imedpub.com/articles/synthesis-andcharacterization-of-polyurethane-nanocomposite-fromcastoroil-hexamethylene-diisocyanate-hmdi.pdf

10. Patel, V. R., Dumancas, G. G., Viswanath, L. C. K., Maples, R., \& Subong, B. J. (2016). Castor oil: properties, uses, and optimization of processing parameters in commercial production. 
Lipid Insights, 9(1), 1-12. http://dx.doi.org/10.4137/LPI.S40233. PMid:27656091

11. Graça, Y. L. S. S., Opolski, A. C., Barboza, B. E. G., Erbano, B. O., Mazzaro, C. C., Klostermann, F. C., Sucharski, E. E., \& Kubrusly, L. F. (2014). Biocompatibility of Ricinus communis polymer with addition of calcium carbonate compared to titanium. Experimental study in guinea pigs. Revista Brasileira de Cirurgia Cardiovascular; Orgao Oficial da Sociedade Brasileira de Cirurgia Cardiovascular, 29(2), 272-278. PMid:25140479.

12. Santos, V. T., Facco, G. G., Ortiz, H. C., \& Silva, I. S. (2017). Behavior study of the doped castor bean polymer rod with bioactive glass and hidroxyapatite in mice fêmur medullary canal. Acta Cirurgica Brasileira, 32(2), 116-124. http://dx.doi. org/10.1590/s0102-865020170204. PMid:28300879.

13. Król, P. (2007). Synthesis methods, chemical structures and phase structures of linear polyurethanes. Properties and applications of linear polyurethanes in polyurethane elastomers, copolymers and ionomers. Progress in Materials Science, 52(6), 915-1015. http://dx.doi.org/10.1016/j.pmatsci.2006.11.001.

14. Dave, V., \& Patel, H. S. (2017). Synthesis and characterization of interpenetrating polymer networks from transesterified castor oil based polyurethane and polystyrene. Journal of Saudi Chemical Society, 21(1), 18-24. http://dx.doi.org/10.1016/j. jscs.2013.08.001.

15. Sathiskumar, P. S., \& Madras, G. (2011). Synthesis, characterization, degradation of biodegradable castor oil based polyesters. Polymer Degradation \& Stability, 96(1), 1695-1704. http:// dx.doi.org/10.1016/j.polymdegradstab.2011.07.002.

16. Zhang, L., Zhang, M., Hu, L., \& Zhou, Y. (2014). Synthesis of rigid polyurethane foams with castor oil-based flame retardant polyols. Industrial Crops and Products, 52(1), 380-388. http:// dx.doi.org/10.1016/j.indcrop.2013.10.043.

17. Lin, S., Huang, J., Chang, P. R., Wei, S., Xu, Y., \& Zhang, Q. (2013). Structure and mechanical properties of new biomassbased nanocomposite: castor oil-based polyurethane reinforced with acetylated cellulose nanocrystal. Carbohydrate Polymers, 95(1), 91-99. http://dx.doi.org/10.1016/j.carbpol.2013.02.023. PMid:23618244.

18. Hejna, A., Kirpluks, M., Kosmela, P., Cabulis, U., Haponiuk, J., \& Piszczyk, Ł. (2017). The influence of crude glycerol and castor oil-based polyol on thestructure and performance of rigid polyurethane-polyisocyanurate foams. Industrial Crops and Products, 95(1), 113-125. http://dx.doi.org/10.1016/j. indcrop.2016.10.023.

19. Mutlu, H., \& Meier, M. A. R. (2010). Castor oil as a renewable resource for the chemical industry. European Journal of Lipid Science and Technology, 112(1), 10-30. http://dx.doi. org/10.1002/ejlt.200900138.

20. Monteiro, A. S. F., Macedo, L. G. S., Macedo, N. L., \& Balducci, I. (2010). Polyurethane and PTFE membranes for guided bone regeneration: histopathological and ultrastructural evaluation. Medicina Oral, Patologia Oral y Cirugia Bucal, 15(2), e401-406. http://dx.doi.org/10.4317/medoral.15.e401. PMid:19767699.

21. Marano, R., \& Tincani, A. J. (2016). Is there an ideal implant for orbital reconstructions? Prospective 64-case study. Journal of Cranio-Maxillo-Facial Surgery, 44(10), 1682-1688. http:// dx.doi.org/10.1016/j.jcms.2016.08.006. PMid:27637477.
22. Costa, A. C. F. M., Lima, M. G., Lima, L. H. M. A., Cordeiro, V. V., Viana, K. M. S., Souza, C. V., \& Lira, H. L. (2009). Hidroxiapatita: obtenção, caracterização e aplicações. Revista Eletrônica de Materiais e Processos, 4(3), 29-38.

23. Sheikh, F. A., Kanjwal, M. A., Macossay, J., Barakat, N. A. M., \& Kim, H. Y. (2012). A simple approach for synthesis, characterization and bioactivity for bovine bones to fabricate the polyurethane nanofiber containing hydroxyapatite nanoparticle. Express Polymer Letters, 6(1), 1-22. http://dx.doi.org/10.3144/ expresspolymlett.2012.5. PMid:24416082.

24. Potter, J. K., Malmquist, M., \& Ellis, E. 3rd (2012). Biomaterials for reconstruction of the internal orbit. Oral and Maxillofacial Surgery Clinics of North America, 24(4), 609-627. http://dx.doi. org/10.1016/j.coms.2012.07.002. PMid:23107429.

25. Alves, E. G. L., Rezende, C. M. F., Oliveira, H. P., Borges, N. F., Mantovani, P. F., \& Lara, J. S. (2010). Avaliação mecânica da placa de compósito de poli-hidroxibutirato e hidroxiapatita em modelos ósseos de gato. Arquivo Brasileiro de Medicina Veterinária e Zootecnia, 62(6), 1367-1374. http://dx.doi. org/10.1590/S0102-09352010000600011.

26. Cangemi, J. M., Santos, A. M., Claro Neto, S., \& Chierice, G. O. (2008). Biodegradation of polyurethane derived from castor oil. Polimeros, 18(3), 201-206. http://dx.doi.org/10.1590/ S0104-14282008000300004.

27. Callister, W. D. Jr. (2002). Ciência e engenharia de materiais: uma introdução. Rio de Janeiro: LTC.

28. Dubois, L., Steenen, S. A., Gooris, P. J. J., Bos, R. R. M., \& Becking, A. G. (2016). Controversies in orbital reconstructionIII. Biomaterials for orbital reconstruction: a review with clinical recommendations. International Journal of Oral and Maxillofacial Surgery, 45(1), 41-50. http://dx.doi.org/10.1016/j. ijom.2015.06.024. PMid:26250602.

29. Stanton, D. C., Liu, F., Yu, J. W., \& Mistretta, M. C. (2014). Use of bioresorbable plating systems in paediatric mandible fractures. Journal of Cranio-Maxillo-Facial Surgery, 42(7), 1305-1309. http://dx.doi.org/10.1016/j.jcms.2014.03.015. PMid:24815762.

30. Al-Moraissi, E. A., \& Ellis, E. 3rd (2015). Biodegradable and titanium osteosynthesis provide similar stability for orthognathic surgery. Journal of Oral and Maxillofacial Surgery, 73(9), 1795-1808. http://dx.doi.org/10.1016/j.joms.2015.01.035. PMid:25864125.

31. Reis, E. C. C., Borges, A. P. B., Oliveira, P. M., Bicalho, S. M. C. M., Reis, A. M., \& Silva, C. L. (2012). Desenvolvimento e caracterização de membranas rígidas, osteocondutoras e reabsorvíveis de polihidroxibutirato e hidroxiapatita para regeneração periodontal. Polímeros: Ciência e Tecnologia, 22(1), 73-79. http://dx.doi.org/10.1590/S0104-14282012005000007.

32. Kanno, T., Sukegawa, S., Furuki, Y., Nariai, Y., \& Sekine, J. (2018). Overview of innovative advances in bioresorbable plate systems for oral and maxillofacial surgery. Japanese Dental Science Review, 54(3), 127-138. http://dx.doi.org/10.1016/j. jdsr.2018.03.003. PMid:30128060.

Received: June 20, 2018

Revised: Nov. 26, 2018

Accepted: Mar. 08, 2019 